\title{
Social Justice Advocacy in Graduate Teacher Education
}

\author{
Amy Gratch Hoyle ${ }^{1}$ \\ ${ }^{1}$ Educational Policy \& Leadership Department, Cabrini University, Radnor, Pennsylvania, USA \\ Correspondence: Amy Gratch Hoyle, Educational Policy \& Leadership Department, Cabrini University, Radnor, \\ Pennsylvania, USA. E-mail: ag3239@cabrini.edu
}

Received: October 23, 2017

Accepted: November 27, 2017 Online Published: December 21, 2017

doi:10.5539/jel.v7n2p1

URL: http://doi.org/10.5539/jel.v7n2p1

\begin{abstract}
This article includes a description and analysis of a graduate teacher education course designed to engage teachers in taking action for social justice. In the course, students participate in a community of learners in which they examine their cultural identities and engage in social justice advocacy work. Students developed content knowledge and pedagogical strategies that they are able to implement in their K-12 classrooms. Findings indicate that through participating in this course students deepen their sense of what social justice is and act in ways that are consistent with that view.
\end{abstract}

Keywords: advocacy, social justice, social justice education, teacher education

\section{Social Justice Advocacy in Graduate Teacher Education}

"Social justice advocacy work means being daring, risk taking and doing things that you wouldn't normally do. It means pushing yourself to new limits and boundaries." (Liz, Final Analysis Paper)

\section{Introduction}

Ami Prichard (2014) argues that "times have changed for educators. It's no longer enough for teachers to close their classroom doors and do a great job with kids." In the current context of education, where educational policies often relegate teachers to the role of technician and accountability pressures reduce the measure of educational achievement to a single test score, the promise of schools to strengthen our democracy and promote democratic values is challenged. Pritchard continues, "I've learned that in today's educational climate we have to harness the power of our roles as educators and community members to advocate for students and their futures" (p. 44). According to Colucci (2014), however, one of the primary beliefs that hold teachers back from leading for educational change is the belief that, "It's not my job to get involved in politics" (p. 5). This article presents findings from a case study of a graduate teacher education course, Teaching and Learning for Social Justice, in which practicing teachers learn to advocate for students through active participation in the community. Through participant interviews, reflective journal entries, and other written assignments, the faculty member teaching the course examined students' commitment to social justice and their engagement in both self-examination and social action. Through Teaching and Learning for Social Justice, graduate students in teacher education, practicing PK-12 teachers, get involved in political advocacy work and through doing so they come to understand that it is "their job" to get involved. In addition to their personal involvement as agents for social change, they develop advocacy skills that can be shared with their K-12 students.

This article includes a description and analysis of this graduate teacher education course designed to engage practicing teachers in taking action for social justice. In the course, students participate in a community of learners in which they examine their own cultural identities and engage in social justice advocacy work. Students in the course examine the local community in terms of social issues impacting education. As a group, they identify and gain expertise around one issue of social justice impacting education in the community. Grounded in their developing expertise and commitment to social justice and the common good, students develop and implement a social justice advocacy project to address the issue. Through this, course students deepen their sense of what social justice is and act in ways that are consistent with that view. The process experienced in the course 
is grounded in self-reflection and critical thinking. It is this process that the teacher education graduate students are able to implement in their own K-12 classrooms.

\section{Context}

The course examined in this paper is situated in a graduate education program at a small Catholic liberal arts University. The University mission is grounded in a commitment to social justice and academic excellence:

[The University] is a Catholic institution of higher education dedicated to academic excellence, leadership development, and a commitment to social justice. The University welcomes learners of all faiths, cultures, and backgrounds and prepares them to become engaged citizens of the world.

While this mission is integrated throughout the graduate teacher education programs, the foundation for this integration is developed in two required educational foundations courses in which students examine issues of social injustice and inequities through sociocultural, historical and philosophical lenses. Most of the student participants in the study have previously completed the two core foundations courses in the Master of Education program at the University. Reflecting the goals of social foundations of education teaching and scholarship, the core courses in the Master of Education program, focus on bringing the mission into the program.

Through these [foundations] courses, students develop a core of common knowledge and a commitment to social justice. Through the foundations courses, students are engaged in rigorous liberal learning experiences that prepare them to deeply, meaningfully, and critically reflect on and tackle some of the big challenges facing education and the world. These courses link intellectual competence with moral development and instill a special concern for those persons who are in need. (Core Course Syllabi)

These foundations courses are grounded in analysis of texts; thus, the outcomes have to do with student understanding of material and concepts. Findings from previous research involving faculty teaching the two core foundations courses indicated that students need to put the theoretical concepts "into action" (Hoyle, 2015). Feedback from students who took the courses indicates similarly that they want experiences to help feel a sense of agency having studied inequities in the educational system. Teaching and Learning for Social Justice is a foundations course in which students and teacher work together to practice social justice. The course examined in this article provides opportunities for teachers to develop advocacy skills and to address issues of social justice both in and outside of the classroom. This both illustrates how doing advocacy work in education benefits teachers and their students and also provides a rich example of how the field can address these issues. As George Wood expressed so clearly (1998), "Only when our schools are communities where social justice is practiced can we claim to be teaching for that justice." (p. 248)

\section{Literature Review}

Deciding to go into teaching must be a decision from the heart. It must come from a moral imperative to ensure the success of all children, and from a deeply held commitment to social justice. (Morefield, 1996, p. 9)

There is a great deal of research calling teacher educators to prepare teacher candidates for increasingly diverse and inequitable schools (Howard, 2006; Dover, 2009; Bell, 2007; Darling-Hammond, 2002). Much of this literature focuses on the role of preservice teacher education programs in preparing teachers to teach for social justice. More attention needs to be paid, however, to ways teacher education for graduate students can inspire practicing teachers to become agents for change with a social justice orientation. Morefield (1996) is right in his assessment that teachers must hold a commitment to social justice. And as teacher educators working with practicing teachers it is important that we recognize our role in promoting this commitment.

Literature supports the need for more democratic curriculum and pedagogy in our K-12 schools and classrooms.

Levine (2007) contended that young people needed opportunities for leading, serving, deliberating, and addressing problems so they can use their 'energy, creativity, resilience, independence, and fresh thinking' (p. 64). He summed up by stating that participating in politics, community affairs, or leadership roles at age fifteen or twenty-two makes it much more likely that an individual will be involved at thirty or forty. Meier (2009) argued... that students need a curriculum that encourages independence and thoughtfulness and an ethic of participation, in short, a curriculum for democracy (Fleming, 2011, p. 40).

A curriculum for democracy, according to Fleming, provides the basis for civic participation and must be central if our democracy is to last. Beyond civic participation, I contend that civic participation specifically aimed at advocacy for social justice is needed if our democracy is to last.

The goal of social justice education is to enable people to develop the critical analytic tools necessary to understand oppression and their own socialization within oppressive systems, and to develop a sense of agency 
and capacity to interrupt and change oppressive patterns and behaviors in themselves and in the institutions and communities of which they are a part. (Bell, 2007, p. 2)

Adams, Bell, \& Griffin (1997) explain that social justice is often defined as both a goal or a product and a process. Social justice teacher education thus must prepare teachers to understand what social justice would look like, the product. The goal of social justice education according to Adams, Bell, \& Griffin (1997) "is full and equal participation of all groups in a society that is mutually shaped to meet their needs" (p. 3). In order to do this, social justice teacher education must examine the impact of power, privilege and social oppression (Picower, 2012; Storms, 2013). Social justice teacher education must also promote the process referred to by Bell in that it must promote social action as a means to gain equity for all citizens (Picower, 2012). It must be "democratic and participatory, inclusive and affirming of human agency and human capacities for working collaboratively to make change" (Bell, 2007, p. 2). According to Bell (2007), "social justice involves social actors who have a sense of their own agency as well as a sense of social responsibility toward and with others, their society, and the broader world in which they live" (p. 2).

While Bell and others have described the process and product of social justice education in helpful ways, according to Irvine (2004), "the field of teacher education has not taken seriously its role to prepare teachers as activists and advocates for social justice (p. xi). McDonald (2008) explains that in order to do this social justice teacher education programs must "shift the focus from efforts to increase prospective teachers' cultural awareness of diversity to encourage teachers' commitments to social change and activism" (p. 152). The course described in this paper provides opportunities for practicing teachers to achieve Bell's goals for social justice education as they develop a sense of their own agency as well as an understanding of oppression and their capacity to change oppressive patterns in society and schools. The course also increases teachers' cultural awareness of diversity. In addition, it makes the shift called for by both McDonald and Irvine in that it incorporates strategies for preparing teachers as activists and advocates for social justice. Reflecting Dover's (2013) description of teaching for social justice, this course "includes explicit instruction about oppression, prejudice and inequity" and "employs pedagogy that (1) creates a supportive classroom climate that embraces multiple perspectives, (2) emphasizes critical thinking and inquiry, and (3) promotes students' academic, civic, and personal growth" (93). In addition, this course reflects Dover's definition of teaching for social justice in that it "makes connections between education and social change through (1) teachers' sense of themselves as social activists, (2) teachers' intent to raise students' awareness of inequity and injustice, and (3) teachers' intent to promote students' social action" (p. 93). As a result of participation in Teaching and Learning for Social Justice, participants express an increased understanding of inequities in society and of their role as teachers and civic agents to challenge these inequities.

This course also helps to prevent feelings of helplessness that can result from critique of oppressive systems. As mentioned, students at the University take two other educational foundations courses. Through these courses they engage in critique of educational reforms and systems of oppression in schools and society. As Ritchie (2012) warns, engaging in such critique and stopping there leads to "despair, hopelessness, and a deterministic sense that things cannot be changed (Bigelow, 2002; Freire, 1970/2005)" (p. 121). Students having taken the course in sociocultural foundations of education regularly express such feelings of frustration and helplessness. Teaching and Learning for Social Justice provides an opportunity for them to take action to transform society and as indicated in the findings presented here, this opportunity energizes them to continued action for social change and to a commitment to empowering their students to get involved in such action.

The foundations course examined in this paper moves the students from theory to practice, providing an opportunity for students to become agents for change as they participate in advocacy work in the community. As a community of learners, students in the course identify an issue of social justice impacting education in the community. Having identified the issue, students gain expertise and develop and implement an advocacy project to address the issue based on a commitment to social justice and the common good. The process experienced in this course engages the students in social justice advocacy and is also one that teachers are able to implement in their own PK-12 classrooms, promoting both civic participation and a commitment to social justice.

There is a substantial literature base describing the process and product of social justice education. The "literature [however] expresses concern at the absence of an explicit social justice emphasis in teacher preparation that draws upon accessible, effective pedagogies" (Adams, 2007, p. 24). The course examined in this article provides an example of an effective pedagogy in teacher education. Ritchie (2012) defines "critical pedagogy and teaching for social justice to mean educational practices that critique societal structures perpetuating injustice and place students and teachers in agentic positions to effect change... attempting to transform inequities by engaging in efforts toward systemic social change" (p. 121). Through this course, 
students in a graduate teacher education program, practicing teachers, have the opportunity to explore oppression and structures perpetuating injustice. As agents for change, the students participate in a social justice advocacy project, engaging in efforts toward systemic social change. The course is grounded in a commitment to social justice education and provides a basis for broader civic participation and is also an example of accessible and effective pedagogy that the teachers can take into their own PK-12 classrooms promoting civic participation and commitment to social justice among their students. For the purpose of the course as well as for this research, it has become important to establish a working definition of social justice advocacy. In its most simple form, social justice refers to the equal distribution of opportunities, goods and services in which an individual's group membership has no impact. Social justice is grounded in values of equity and the dignity and rights of every human being. Advocacy is activity taken to influence political and social policy in institutions and in society generally. Social justice advocacy is thus taking action designed to bring about more just and equitable social and political policies and practices. This course is grounded in the belief that while advocacy can be an individual or group activity, it is more likely to have an impact when taken collectively.

\section{Teaching \& Learning for Social Justice: The Course}

The overall goal for students in Teaching and Learning for Social Justice is that by the end of the course each student will understand their own and others' views, beliefs, and perspectives on social justice and recognize how our actions (or inaction) contribute to the possibilities we have to experience social justice in our lives and in our communities. In addition, students gain knowledge and pedagogical strategies to bring social justice action into their P-12 classrooms. Critical pedagogy and a focus on reducing human suffering and promoting social justice, form the basis of the course. All course discussions and assignments reflect an understanding that, "critical teachers must understand not only a wide body of subject matter but also the political structure of the school," and society (Kincheloe, 2008, p. 3).

According to Kincheloe (2008), critical pedagogy has several central characteristics including, but not limited to, the following: Critical pedagogy is grounded on a social and educational vision of justice and equality; critical pedagogy is constructed on the belief that education is inherently political; critical pedagogy is dedicated to the alleviation of human suffering; critical pedagogy involves teachers as researchers; and, critical pedagogy is interested in maintaining balance between social change and cultivating the intellect. The course described here reflects each of these characteristics. Initially, students examine their own cultural identity, privilege and taken-for-granted beliefs about "others" as they begin to develop a vision of justice and equality. Through examination of readings, students gain understanding of structural discrimination and inequitable structures and practices in schools thus recognizing the inherent political nature of schooling. As students examine various social issues they continue to develop a vision of social justice as well as a commitment to end human suffering. The students and teacher conduct research throughout the course while cultivating their intellect as well as a growing commitment to social change.

Teaching and Learning for Social Justice is modeled in part on My Voice, a curriculum developed for K-12 classrooms. Need in Deed, the organization responsible for this curriculum, is committed to "prepar[ing] young people for civic responsibility and service to others, enabling them to become capable, contributing members of their community... [They] listen to students voice their concerns about the world around them and support them in taking positive action in response to these concerns" (Need in Deed, p. 2). The curriculum is organized around five sections: Value your voice, Open the issue, Identify the objective, Conduct meaningful service, Evaluate and celebrate. The graduate course modeled after the Need in Deed curriculum focuses on developing cultural competence, analyzing the community through an asset-based lens, identifying a need in the community and finding a way to engage in advocacy around that need. The course build's on Freire's notion of problem-posing, engaging students in an inquiry-based approach to learning, in order for the students to develop both disposition and pedagogical strategies that will enhance their work with their own students (Freire, 1971). Throughout the course, students are moving between theory and practice as they develop knowledge and skills they can bring to their own K-12 classrooms.

The reading and writing assignments in the course are all tied to completing the "Social Justice Action Project".

It is not enough to learn about social justice through readings and discussions; we must act on it in ways large and small, and analyze our actions and the reasons for them in a public context. This is why I have labeled this project "social justice action". Through this approach there is the possibility of generating a deeper learning of and commitment to social justice than mere abstract discussions of social justice theories can do alone. The action serves an additional purpose. At the end of this course, I want us to have a more sophisticated understanding of ourselves as moral agents. What I mean is that I want us to understand that our views, beliefs, and perspectives on 
social justice affect our actions... We have more power to make a just society than we think. Through this social justice action project, I hope you get a sense of that power through the small contributions you will make. (Social Justice Action Project)

This project has several components that develop students' skills in critical thinking, research, presentation, action and reflection. While the project is completed as a whole group, each student submits work independently at various times throughout the course. Students complete weekly reflections which are submitted online. Most reflections are responses to prompts related to the issue and the action in the course. Students also reflect on what the work in the course means in terms of their own P-12 teaching practice. During the first weeks of the course, the students and instructor work as a group to explore the concepts of privilege and structural inequality and students complete written reflections around these topics. In addition to the weekly reflections, each student prepares a written analysis of research. Students analyze research in the literature initially in order to present a topic for study to the class. Students debate the issues presented and come to consensus. In fall 2015, this debate led to a decision to study poverty, focusing on its impact on schools and children's education in the neighboring city. Once the topic is determined, students continue to prepare written analyses of research which they share through written and oral presentations with other members of the class. In fall 2015, the students compiled the most significant research findings in the literature on poverty into an annotated bibliography. Guest speakers are invited to class to speak about the issue itself, about bringing social justice education into the PK-12 classroom, and about doing advocacy work. With the support of the instructor and the guest speakers, students work as a group to develop an action plan.

In fall 2015, after studying the causes and effects of poverty, students created a postcard to send to members of the state legislature to advocate for a fair funding formula for education. Students invited other educators to write a story about the impact of poverty in their classrooms on each postcard and over 50 postcards were sent to legislators. In addition to the personal stories, the postcards included the statement, "Support a fair funding formula and increase school funding". In addition to the postcard, students worked as a group to create a resource list for parents and teachers which included websites, addresses and phone numbers for numerous organizations in the area that provide support for poor and homeless families. While this work was done collaboratively, each student wrote a Final Analysis Paper in which they examined the literature and the action taken; described how the action affected them individually; and, described the responses to the action and the impact they think the action had. Because one of the goals of the advocacy project is to gain a better sense of self as moral agent, reflections on the action in the paper included exploration of self as agent for change. For most students these reflections also included discussion of how the experience will impact their work as classroom teachers.

\section{Methods}

The approach to this qualitative study is aligned with approaches described by Strauss \& Corbin (1990). Through identification of themes and the use of axial coding, the researcher has reconstructed the data into a recognizable reality, the reality of both the impact of the course as well as of how the course is experienced by the students. While the primary aim of this research is description of this "reality", the analysis allows for theory-building as well. Data sources collected during this study include student reflective journal entries; questionnaires administered at the start and the end of the course; student final analysis papers; interviews with students; and a $\log$ kept throughout the semester by the instructor. Initial interview questions focused on advocacy work: How do you define social justice advocacy work? How you ever been involved in social justice advocacy work? What are your hopes and concerns related to participating in social justice advocacy work? Topics for journal entries were generally self-selected by individual students. Questionnaires included questions related to social justice as well as to expectations for and experiences in the course: How do you define social justice? How do you define social justice education? What are your expectations for the course? What did you find most rewarding about the course? What has been most challenging in the course?

Using the constant comparative method for data analysis, themes were identified and data coded. In this grounded theory approach, the constant comparative method was used and as each new theme emerged for analysis, it was compared to other themes. The analysis was ongoing and iterative allowing for continuous refinement of themes. Out of the process of inductive reasoning, what is important emerges from the data itself.

Eight overall themes or categories emerged from the data:

1) Personal goals and their shift over the course of the class

2) Understandings of advocacy work 
3) Descriptions of social justice education practices and goals

4) Conceptions of social justice

5) Value of community in advocacy work

6) Shift in perspective regarding poverty

7) Benefits and weaknesses of class assignments and activities

This article focuses on the first three and how the students see their work as agents for change through their own advocacy work and the work they now plan to do with their P-12 students. The data presented in this article is textually rich, using the students' words to illustrate key findings. From these findings it is possible to identify lessons learned from the study regarding how doing advocacy work in teacher education benefits students and allows P-12 teachers to develop advocacy skills needed to address issues of social justice both in and outside their own classroom.

\section{Participants}

In fall 2015 there were seven students enrolled in Teaching and Learning for Social Justice and all seven agreed to participate in the research study. While five students self-selected into the course based on personal interest, two were assigned to the course when another required course was cancelled. Six of seven students are female. The single male student and one of the females are African American and the other 5 students self-identify as White. All seven students are currently teaching in P-12 classrooms, 4 in urban settings and 3 in suburban (more affluent) districts. One teaches in a private preschool, one in an elementary charter school, and one in a secondary cyber charter school. The other four teach in regular public schools at the elementary and secondary levels. While the group is small in size, participates indicate in the data that the diversity of experiences among members is important to the work done in the course. This finding will be explored further in a separate article.

\section{Results \& Discussion}

The course, Teaching and Learning for Social Justice, was offered for the first time in fall 2015. As indicated above, the overall goal of the course is that by the end of the course each student will understand their own and others' views, beliefs, and perspectives on social justice and recognize how our actions (or inaction) contribute to the possibilities we have to experience social justice in our lives and in our communities. In addition, through participation in the course students will gain knowledge and pedagogical strategies to bring social justice action into their P-12 classrooms.

The syllabus lists the following learning outcomes for the course:

1) Students will develop or increase an existing commitment to social justice

2) Students will increase understanding of their own cultural identities and gain respect for diverse identities

3) Students will understand the relationship between schools and society in terms of a specific social issue

4) Students will develop a more sophisticated understanding of social justice

5) Students will exhibit evidence of leadership in the service of others, as engaged citizens of the world.

6) Students will critically analyze the impact of their work as agents for social change

7) Students will gain content knowledge and pedagogical strategies to promote action for social justice in PreK-12 classrooms.

While the learning outcomes were reviewed thoroughly during the initial class meeting, students' understanding of the course goals were more general prior to this time. Prior to enrolling in the course students' knowledge about the course was limited to the institution's course description:

As a community of learners, students will identify an issue of social justice impacting education in the community. Having identified the issue, students will gain expertise and develop and implement a community service project to address the issue based on a commitment to social justice and the common good. The process experienced in this course is one that teachers will then be able to implement in their own K-12 classrooms. (Cabrini University, 2017, p. 109)

During the initial class meeting the instructor and students discussed this description, focusing on the "community service project". While this is the language used in the Catalog Description, the focus of the course is on a social action or social advocacy project and it was essential to distinguish this work from "community service". Community service is similar to advocacy work in that it is performed by someone or a group of people for the benefit of the public. Advocacy work, however, is also and perhaps more importantly a political process which 
aims to influence decisions within political and social systems and institutions. As reflected in the findings below, this more political aim of the course made some students uneasy. It is through the Social Justice Action Project that students experienced a shift in attitude about advocacy work as well as in their personal goals. In addition, this advocacy project resulted in students' more complex conceptions of social justice and social justice education. These findings are illustrated below through the words of the participants.

\subsection{Understanding of Advocacy}

As noted above, the claim in the course description that the course includes a "community service project" is problematic and it was apparent at the outset of the course that the instructor needed to guide students in problematizing the loose interchange of words around advocacy. The instructor came to the course with the assumptions that advocacy has to do with influencing political decisions and that this work is essential in order to address issues of inequity and oppression in society and schools.

The students' initial conceptions of advocacy work are reflected in the students' questionnaire responses written during the first class session in response to the question, 'How do you define or describe social justice advocacy work?' (9/2/2016):

- "Advocacy work is working to promote or make a difference in the world."

- "I think social justice work is providing community based volunteer work to promote justice for the dignity and well-being for ALL!!"

- "Social justice advocacy work gives a voice to the individuals and groups who are struggling to find theirs. This type of advocacy also should motivate and encourage those who have lost hope and feel stuck."

- "I think the advocacy part transitions the 'participant' into a developer or generator of action, requiring more leadership and perhaps sales skills than just joining a group or volunteering."

- "I would define [social justice advocacy work] as lobbying, and petitioning for certain laws to be changed. Also participating in community projects."

While these initial answers reflect the political nature of advocacy work, discussions in class and reflective journal entries reflected resistance to doing work seen as political in spite of a desire to "make a difference". For instance, Erica expressed this resistance explicitly in reflective journal entries. (Pseudonyms are used throughout the paper.) Erica, after discussions in class about doing advocacy work and not "community service" wrote, "I was not thinking of a political move for this project. I am more than willing to do what the group decides, but I was thinking something more powerful to directly affect those who are struggling. I was hoping to compose a resource list to distribute to the district and make available to those in the community" (Erica, Journal 9). The fact that Erica believed this type of service is "more powerful" than political action raises questions about student understanding of structural inequity and of inequality as a primary concern when confronting social problems such as poverty. While the students studied poverty as a political and social issue, Erica did not see the value of a project aimed at bringing about structural change. While this perspective deserves attention in the class, it appears that most of the students formed a different perspective and the social action project in class both clarified understanding of advocacy work and inspired desire to continue doing such work.

Kate's journal reflects her growth in this area when she wrote, "I have always been one to avoid politics-I am non-confrontational and have leanings toward a both parties in different areas - so never felt comfortable being very vocal toward one party or another. However, I do have some solid standing on issues - this being one of them and my eyes have been opened to the possibility that even a few voices can be heard exponentially" (Kate, Journal 9). While her initial response to doing advocacy work reflected her desire to avoid politics, she came to believe that this may be most effective in making voices heard. In several journal entries Kate mentioned group discussions and a guest speaker as important in influencing this shift. The guest speaker, an experienced activist spoke about a range of advocacy projects through which she worked with others to influence political and social change. Susan reflects a similar shift when she writes, "I never thought I would do anything of this nature, I think the post card idea is both doable and could have exponential effects" (Susan, Journal 9). Other students in the class also referred to this speaker as important in their transformation from concerned citizen to agent for change. Liz explained that, "before we met in class last week and heard [the guest speaker] discuss her take on poverty and the role her organization does to advocate for issues, I had in mind that we could possibly provide information to other teachers... As a class, it would be most effective if we did some kind of advocacy work" (Liz, Journal 9). Mary explained in her final paper that "this advocacy work has shown me how I can get directly involved with fighting for social justice. I was extremely inspired and motivated by the guest speakers that we had come to our class this semester. The first guest speaker we had works for an organization that directly fought 
injustice and inspired me to get involved" (Mary, Final Action Project). In general, as suggested by Liz's comment introducing this article, the initial resistance to advocacy work was replaced by enthusiasm and excitement about continued involvement in social justice work.

\subsection{Personal Goals}

Another theme found in the students' reflective journals and other written assignments is individual student personal goals related to social justice advocacy. Similar to the shift described above related to understanding of advocacy work, the evolution of personal goals during the course reflects increased interest in and enthusiasm about participating in social justice advocacy work. Early in the course the seven students expressed their goals in general terms. For example, when asked in the initial interview, "What are you hopes and concerns related to participating in social justice advocacy work through this course?" students gave the following responses:

- "I hope to make a difference in our community."

- "I hope to become involved in future advocacy situations."

- " "I hope to broaden my perspective of different communities and the valuable role I can play."

- "I would like to actively promote change."

- "I hope that I can become a doer."

- " $\quad$ I hope for the broader picture, to learn how to be an initiator of change."

- "I feel inspired to be a member of a group who wants to identify a tough issue and really make an impact on the community."

These responses were anonymous so it is difficult to analyze shifts in individual perspectives. Nonetheless it is worth noting that the first six responses are broad and seem to reflect a superficial commitment to participating in social justice advocacy. It is only the last response that begins to suggest the more complicated work that lies ahead in the course.

At the end of the course, students express more complex reflections on their roles in and goals for social justice advocacy. In her final paper, Erica expresses two views shared widely among the students when she says, "As a teacher I feel strongly that we have to advocate for all students... I believe we teach to make a difference in the lives of children, and that can go beyond your one class each year. I feel as teachers we can work together to help make a difference for America's future, our students" (Erica, Final Analysis Paper). In the final paper, five students specifically mentioned the importance of working together, collaborating, to bring about social change. In addition, each student expresses in either the final paper and/or the final reflection the belief that through social advocacy work s/he could make a difference for her/his own students.

As suggested earlier, another shared goal at the end of the course is to continue doing advocacy work after the end of the course. Students' personal goals in regards to this social justice work are more fully developed and reflect a greater sense of confidence and clarity:

- $\quad$ "This project has led me to have a commitment to fight for those children [living in poverty]. I feel a moral responsibility to continue to be a voice for these struggling students, beyond our classroom project" (Susan, Final Analysis Paper).

- $\quad$ "This semester has driven me to become more passionate about others and inspired me to continue learning as much as I can about social justice and how I can take action. I plan to continue to take action far beyond just this course" (Mary, Final Analysis Paper).

- $\quad$ "We can continue to advocate on our own without the class through the pamphlets and our knowledge on the subject" (Mary, Journal 9).

The greater commitment to and confidence about doing social justice advocacy work is a significant gain from the course. It is important that further research investigates how the students have continued this work both inside and outside of their classrooms.

\subsection{Social Justice Education}

In addition to the evolution of their understanding of and goals around doing social justice advocacy work, student reflections suggest increased commitment to and understanding of social justice education. Initially, student suggestions in regard to education for social justice are all related to the curriculum and most students indicate the belief that "social justice" is already integrated into the curriculum: 
- $\quad$ "Social justice issues should absolutely be part of the school curriculum and I think can be incorporated in my 'natural' ways as well as more formal and 'intentional"' (Kate, Reflective Journal 2).

- "Social justice in the PreK-12 setting is very important. To be a teacher is to show respect for children and their backgrounds, cultures, learning needs, etc. In a socially just system, children should be enabled to achieve their full potential in academics. Social justice education should be woven into parts of the school's curriculum" (Erica, Reflective Journal 2)

- "The idea of Social Justice is and will always be an important part of any school's curriculum" (Liz, Reflective Journal 2)

- "I believe social justice should be a part of the curriculum in every school" (Joe, Reflective Journal 2)

As students participated in the course, findings revealed several changes reflecting a more complex understanding of both the why and the how of social justice education.

Students value the content knowledge from the course. For instance, Mary explains that through her knowledge of the causes and effects of poverty she is "better able to realize possible causes and effects of students not being successful in the classroom. After learning so much and growing so much as a person I no longer judged. I was not able to end poverty, but I was able to change my mindset and that is an important start in the fight against poverty" (Mary, Final Action Paper). The impact of the study of poverty on students' mindsets will be analyzed and described in detail in a separate article. Here the focus is on the development of both pedagogical strategies (the how) and moral obligation (the why) evidenced in the data.

Throughout their final action papers students articulate pedagogical strategies to promote social justice and equity in their classrooms and through their teaching:

- "I would do this project with my students so they could have a better perspective of the world around them" (Erica, Reflective Journal 6).

- $\quad$ "I would look for ways to weave this project into my curriculum, potentially in social studies. We do a unit on our community, and this unit could be an opportunity to incorporate some aspect of social justice exploring" (Susan, Reflective Journal 6).

- $\quad$ "I think that a social justice curriculum would be very beneficial for students in a K-12 setting. I believe that the best way to learn about social justice is to participate in a hands on project like we are in EDG 591. I think that through the course students should learn what social justice is, what social justice issues exist, why these social justice issues exist, what's being done to fight social justice issues, and how to get involved in fighting for social justice" (Kate, Reflective Journal 6).

- "I think that a process similar to the process we have used during EDG 591 would be effective for K-12 students. I think that first students need to learn what social justice is and then they need to learn what social justice issues exist. Once students learn about social justice issues, I think that they need to research the issues and focus on one issue at a time to learn more about each issue" (Mary, Reflective Journal 6).

As intended in the course design, the Social Justice Action Project in the course is a model for students, providing pedagogical strategies which they now plan to implement in their own classrooms. Through the course project and assignments, students met the learning outcomes including the last, "Students will gain content knowledge and pedagogical strategies to promote action for social justice in PreK-12 classrooms".

Students also have a reason why they want to bring such a project into their classrooms, expressing a moral obligation to do this work:

- "As a teacher I feel strongly that we have to advocate for all students" (Erica, Final Analysis Paper)

- $\quad$ "I feel it is my job to be an advocate for [my students]. It is not morally right that all children are not receiving the same opportunities" (Susan, Final Analysis Paper).

- "As a teacher I have the lives of students and their future aspirations in my hands every day. In that capacity I must promote social justice" (Joe, Final Analysis Paper).

- $\quad$ "It will be incumbent on me to always have a heightened sense of awareness to these (social) issues and be thinking of ways that I can help my students overcome the negative effects that these issues may be having on their education and on the quality of their lives" (Mary, Final Analysis Paper).

Findings indicate that students developed a greater moral commitment to advocating for students. Again the course learning outcome, "Students will develop or increase an existing commitment to social justice," is met through having experienced the course. As Pritchard notes (2014), teachers must do more than teach, they must 
advocate for students. And while many teachers do not want to get involved in politics (Colucci, 2014), courses such as the one described in this paper can prepare teachers with the skills and attitudes necessary to do this essential political work. As suggested throughout the literature described earlier in this paper, the commitment of teachers to social justice along with the increased pedagogical knowledge and skills is essential for the promotion of social justice education.

\section{Conclusions}

Findings from this research indicate that students in the course, Teaching and Learning for Social Justice, gain an increased sense of commitment to social justice advocacy and also gain pedagogical knowledge important to bringing social justice education into their classrooms. For the seven students in the course in fall 2015 it has become "their job" to get involved even when this means taking political action. It is apparent from this research that uneasiness about advocacy work is lessened when experienced, especially when the experience is shared with others.

Moving forward it may be important to correct the course description, replacing "community service" with "social justice advocacy". This change, however, may deter some students from enrolling in the course. It will certainly be important to continue to have students compare their notions of advocacy work to community service, charity and volunteer work at the start of the course. In addition, reflecting on the impact of these different types of work is important.

In addition, while the students express a desire to continue to do advocacy work and to bring social justice education into their classrooms, research is needed to see what each student is doing both inside and outside of the classroom. The value of the course rests largely on the students' continued work over time.

As mentioned in this article, several other themes emerged from the research: student conceptions of social justice, the value of community in doing advocacy work, and the shift in perspective regarding poverty. These themes need to be analyzed more fully in order to gain a richer understanding of the impact of the course and in order to continue to improve the course moving forward.

The students in Teaching and Learning for Social Justice deepened their sense of what social justice is and began to act in ways consistent with that view. They appreciated the opportunity to develop advocacy skills and to address issues of social justice. Findings from this research illustrate how doing advocacy work in graduate teacher education benefits teachers and their students. The course is an example of how engaging in collaborative advocacy work in teacher education programs can help address the need for teachers to engage in social justice work.

\section{References}

Adams, M. (2007). Pedagogical frameworks for social justice education. In M. Adams, L. A. Bell, \& P. Griffin (Eds.), Teaching for diversity and social justice (2nd ed., pp. 15-33). New York: Routledge.

Adams, M., Bell, L. A., \& Griffin, P. (Eds.) (1997). Teaching for diversity and social justice: a sourcebook. New York: Routledge.

Bell, L. A. (2007). Theoretical foundations for social justice education. In M. Adams, L. A. Bell, \& P. Griffin (Eds.), Teaching for diversity and social justice (2nd ed., pp. 1-14). New York: Routledge.

Cabrini University. (2017). Cabrini University graduate catalog, 2017-2018. Unpublished, Cabrini University, Radnor, Pennsylvania.

Colucci, A. S. (2014). Five beliefs that hold teachers back from leading. Education Week, 5.

Committee on Academic Standards and Accreditation. (2013). Standards for academic and professional instruction in foundations of education, educational studies, and educational policy studies, 3rd edition, 2012, draft presented to the educational community by the American Educational Studies Association's Committee on Academic Standards and Accreditation. Educational Studies, 49, $107-118$. https://doi.org/10.1080/00131946.2013.767253

Darling-Hammond, L. (2002). Learning to teach for social justice. In L. Darling-Hammond, J. French, \& S. P. Garcia-Lopez (Ed.), Learning to teach for social justice (pp. 1-7). New York: Teachers University Pr.

Dover, A. G. (2009). Teaching for social justice and K-12 student outcomes: A conceptual framework and research review. Equity \& Excellence in Education, 42(4), 506-524. https://doi.org/10.1080/10665680903196339 
Dover, A. G. (2013). Getting "up to code": Preparing for and confronting challenges when teaching for social justice in standards-based classrooms. Action in Teacher Education, 35(2), 89-102. https://doi.org/10.1080/01626620.2013.770377

Fleming, L. C. (2011). Civic participation: A curriculum for democracy. American Secondary Education, 40(1), 29-50.

Freire, P. (1971). Pedagogy of the oppressed. New York: Pantheon.

Hackman, H. W. (2005). Five essential components for social justice education. Equity \& Excellence in Education, 38, 103-109. https://doi.org/10.1080/10665680590935034

Howard, G. R. (2006). We can't teach what we don't know: White teachers, multiracial schools. New York: Teachers University Pr.

Hoyle, A. (2015). Teaching for social justice in graduate teacher education. Unpublished manuscript, Educational Policy \& Leadership Department, Cabrini University, Radnor, Pennsylvania.

Irvine, J. J. (2004). Forward. In M. Cochran-Smith (Ed.), Walking the road: Race, diversity, and social justice teacher education (pp. xi-xiv). New York: Teachers University Pr.

Kincheloe, J. L. (2008). Critical Pedagogy: Primer (2nd edition). New York: Peter Lang. https://doi.org/10.1007/978-1-4020-8224-5

McDonald, M. A. (2008). The pedagogy of assignments in social justice teacher education. Equity \& Excellence in Education, 41(2), 151-167. https://doi.org/10.1080/10665680801943949

Morefield, J. (1996). Recreating schools for all children. Retrieved from http://newhorizons.org/article-morefield.html

Need in Deed. (2014). My voice: A service-learning framework for teachers. Philadelphia, PA: Author.

Picower, B. (2012). Practice what you teach: Social justice education in the classroom and the streets. New York: Routledge.

Preskill, S., \& Brookfield, S. D. (2000). Learning as a way of leading: Lessons from the struggle for social justice. San Francisco, CA: Jossey-Bass.

Prichard, A. (2014). When all else fails, organize and advocate. Phi Delta Kappan, 44-48.

Reed-Bouley, J., \& Kyle, E. (2015). Challenging racism and white privilege in undergraduate theology contexts: Teaching and learning strategies for maximizing the promise of community service-learning. Teaching Theology and Religion, 18(1), 20-36. https://doi.org/10.1111/teth.12260

Richie, S. (2012). Incubating and sustaining: How teacher networks enable and support social justice education. Journal of Teacher Education, 63(2), 120-131. https://doi.org/10.1177/0022487111428327

Storms, S. B. (2013). Preparing teachers for social justice advocacy: Am I walking my talk? Multicultural Education, 33-39.

Strauss, A., \& Corbin, J. (1990) Basics of qualitative research: Grounded theory procedures and techniques. Newbury Park, CA: Sage.

Tinkler, A., Tinkler, B., Gerstl-Pepin, C., \& Mugisha, V. M. (2014). The promise of a community-based participatory approach to service-learning in teacher education. Journal of Higher Education Outreach and Engagement, 18(3), 209-232.

Wood, G. (1998). In W. Ayers, J. A. Hunt, \& T. Quinn (Eds.), Teaching for social justice (p. 248). New York: The New Press.

\section{Copyrights}

Copyright for this article is retained by the author(s), with first publication rights granted to the journal.

This is an open-access article distributed under the terms and conditions of the Creative Commons Attribution license (http://creativecommons.org/licenses/by/4.0/). 